try information are included in the syllabus prepared by the Business Communications Department and distributed to all students taking "Business Communication." The guides are also available in the Business Administration/Government Documents Department and in the Reading Room in the College of Business Administration. They have proved to be useful in numerous other classes and have saved considerable staff time. Students using the guides may help themselves in most instances.

Orienting undergraduates in business to the library is a relatively easy task: graduate students in business are another matter. They are more diverse in their information needs and require a higher level of library support. Many business graduate students are unfamiliar with business research materials because they come from other disciplines. Doing library research is often a frustrating experience because of their unfamiliarity with business information sources.

Realizing this frustration, the staff of the Business Administration/Government Documents Department decided to initiate a library orientation program for graduate business students. The orientations are planned around a two-hour block of time and offered on a weekday morning, a weekday evening, and a Saturday morning.

The orientations are publicized by sending memoranda to the deans and chairmen of all the departments in the College of Business Administration, placing posters in the Business Administration/Government Documents Department and in the College of Business Reading Room. and having announcements appear in the campus newsletter, "FY'I," and the daily newspaper. "The Reveille," The most effective method of publicity seems to be simply word of mouth. Students are asked to call for a reservation on their preferred dav. It should be noted that these orient ations are not held in conjunction with any class and students come during their own free time.

The orientations are planned to cover as much information as possible during the two-hour period. The sessions begin with a general introduction to the organization and service points in the $\mathrm{l}$ brary. Suggestions on how to more effectively use the card catalog are given. Since periodical indexes are one of the most important access tools to business information, the major periodical indexes are discussed as well as procedures for locating periodicals in the Middleton Library: Research guides and bibliographies are presented as aids to locating information beyond the card catalog and periodical indexes. Considerable time is spent on statistical sources and how to locate and use government documents. The sessions are concluded with a demonstration of bibliographic and non-bibliographic database searching.

These sessions for graduate business students seem to have inmediate results. A marked difference may be noted in use of the library by students attending the sessions versus those still trving to fumble their way through the information maze. They also allow for the development of a closer working relationship between the librarians and students.

Library instruction at LSU is also offered through a one-credit course called "Introduction to the Use of the Library" and through numerous classroom presentations made by reference librarians.-Milton G. Ternherg. Middleton Library, Louisiana State University. Baton Rouge.

\section{BI Exhibit Update}

\author{
Carolyn Kirkendall \\ Project LOEX
}

In the past two months, many requests to borrow the BI Liaison Project display have been received, and many more opportunities to exhibit the module have been identified. I'm also happy to report about sev'eral presentations at conventions and association meetings:

Marilyn Lutzker, Head of Reader Services at the John Jay College Library, presented a paper on "Use of Primary Resources for Undergraduate Tern Papers in Criminal Justice" at the Academy of Criminal Justice Science's annual conference in February at San Antonio. A Roundtable on Criminal Justice Research Resources has been formed within the Academy:

Negotiations are progressing for sponsoring a drop-in session using the ACRL BI Liaison Project exhibit at the Fall meeting in Toronto of the American Council on Education. Our proposal was not accepted for program agenda.

The Program of the National Conference on Teaching Excellence, sponsored by the NISOD at the University of Texas at Austin, will include a presentation by John Kupersmith, Assistant for Public Services Programs at the General Libraries of UT-Austin. The ACRL BI Liaison Project exhibit will also be on display at this May 24-27 Conference.

Peggy: Toifel of the University of West Florida Library participated in the program of the Council on Social W'ork Education's annual meeting last month in Fort Worth, and her presentation was accompanied by the exhibit.

The exhibit was also part of the Idea Mart Booths. a feature of the recent convention of the American Association of Higher Education in W'ashington. D.C. In .May. promotional literature 
about the Integrating Libraries Into Higher Education project will be distributed at the National Art Education Association's annual meeting in Detroit. The display itself will also be a part of the American Association for the Advancement of Science exhibits at their conference next month, also scheduled for Detroit.

The project director promoted the BI cause by speaking at the recent Michigan Academy of Arts, Letters and Sciences annual meeting. The display was featured at a Michigan Library Association workshop on "The Role of the Library in the Academic Environment," held in East Lansing last month.

This month, the BI display will be included at sessions of the Oregon Library Association, the

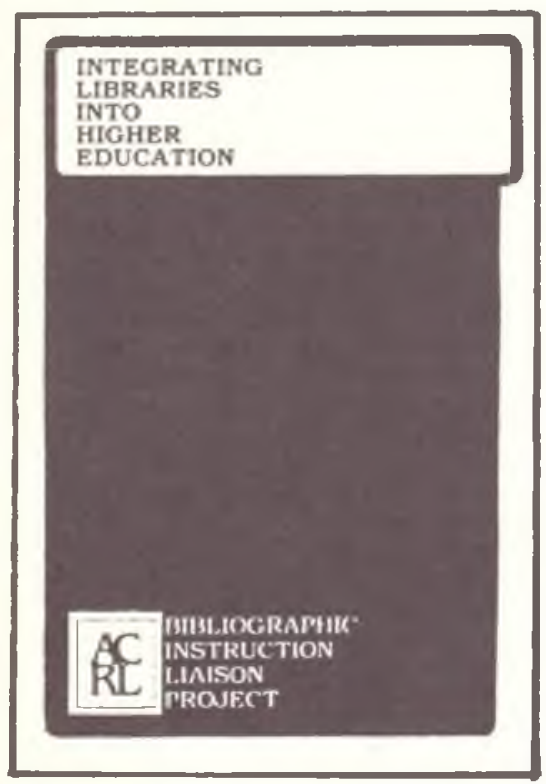

Connecticut Library Association, the Midwestern Sociological Association meeting in Kansas City, and at a BI Conference sponsored by Ohio State University.

Volunteers are needed to help staff the exhibit in Los Angeles for the ALA summer meeting. Please contact me if you have a free hour or two and would like to help promote our project in this fashion.

Copies of the ACRL BI Liaison Project's press kits are now available for purchase by individuals. Profits received from selling these packages individually will go to def ray the costs of their printing and compilation.

Included in the packages-and there are eight separate subject ones available: psychology, sociology, history, language \& literature, fine arts, sciences, political sciences, education, and business \& management - are reprints of articles on the role of the academic library in higher education and how librarians can assist teaching faculty to promote the teaching/learning process, a brochure explaining the project, a short reading list of appropriate articles and books, and a collection of eight to ten sample materials produced by academic libraries to facilitate literature searching.

These kits were originally designed to distribute to the office staff and convention program chairs of associations in higher education. They could also be very handily used by librarians on their own college and university campuses to explain and promote BI among teaching faculty and department heads, to illustrate what other academic libraries have done to assist the integration of library skills into their curricula.

A separate general press kit of materials on the importance of BI and the library's role is also available, and includes a variety of teaching guides from various disciplines and institutions.

You can help! We need your contributions of pathfinders, exercises and sample guides from the subject areas listed above. If you would like your library represented in these packages, please send 25 samples of appropriate materials to the Project Director, or call me for more information.

I've enclosed $\$ 10.00$ (ACRL member)

$\$ 12.00$ (non-member) for each. Make check payable to: Eastern Michiqan University - Account \$24144.

Name

Position

Address

Street or P.O, Box

City Institution

Mail this order form to: Carolyn Kirkendall-BI Liaison Project Director, Z LOEX Clearinghouse, Center of Educational Resources, Eastern Michigan University, Ypsilanti, MI 48197. Prepayment is required! 